\section{Foreigners join MITI's club}

\section{Tokyo}

LAST week, a large group of senior officials from Japan's Ministry of International Trade and Industry (MITI) held a first informal meeting with a handful of foreign science correspondents based in Tokyo in an attempt to open new lines of communication between the ministry and the foreign press.

The meeting may not seem like a historic event. But in Japan, it marked an unprecedented breakthrough that should allow more open coverage of MITI's activities in science and technology. Bob Johnstone, science and technology correspondent for the Far Eastern Economic Review, and several MITI officials organized the meeting. Like many foreign correspondents in Japan, Johnstone is frustrated by the lack of information provided by government organizations.

At the meeting, 25 senior officials from MITI's Agency of Industrial Science and Technology (AIST) promised to open new channels of communication by providing press releases, holding press conferences for the foreign press and, more important, by arranging regular, informal meetings with senior AIST officials.

At present, almost all government information is fed to exclusive private press clubs ('kisha' clubs) connected to each ministry or organization. Until recently, nearly all of these clubs were closed to foreigners. Although the Foreign Press Club in Tokyo has led a long campaign to open all such clubs to foreign members, the advantages of joining may be questionable.

Japanese kisha club members virtually live in the organizations they cover. The clubs are located on the ministry premises and beds are provided for journalists who want to stay overnight.

Because reporters from many (but not all) newspapers are assigned to particular clubs for long periods, there is a strong incentive for them not to upset the organization in which they are located.

As a result, the clubs sometimes seem to be more like public relations departments than press organizations and critical review of government policy may be lacking.

MITI officials will be disappointed if they expect the new 'club' of foreign science correspondents to behave like kisha club members. But MITI seems well aware of the differences between the foreign and Japanese press.

Masaru Sugiura, director-general of AIST, in his opening address to foreign correspondents, noted that "the value of information is often construed as different between the party retaining and distributing such information and the receiving party thereof" and "that this is particularly true between the Agency and the foreign press". Nevertheless, he asserted that "information gaps that may exist between us should be immediately dissolved, and information on Japan's science and technology policies should be given properly to foreign press representatives and correspondents".

MITI's move to open new communication channels comes at a time when the ministry is actively trying to international-

\section{PUBLIC HEALTH \\ Bad blood between Red Cross and FDA}

The American Red Cross came under fire last week from the US Food and Drug Administration (FDA), which issued a preliminary report claiming that several hundred instances of errors or accidents in the collection and distribution of blood were not reported promptly to the FDA but languished instead at national Red Cross headquarters in Washington, DC.

At a hearing on the safety of the nation's blood supply, a congressional subcommittee on oversight and investigations, chaired by Representative John D. Dingell (Democrat, Michigan), set out to determine whether the lessons of the $1980 \mathrm{~s}$, when tardiness in dealing with HIV (human immunodeficiency virus) contamination shook public confidence in the blood supply, had been heeded by the blood banking industry and government regulators. As Dingell said, the inquiry "focuses on whether the blood supply is as safe at it could be or should be".

The subcommittee heard FDA charges that the American Red Cross, which supplies about half of the nation's blood supply, either failed or was slow to report to the FDA 386 error and accident reports. The FDA requires that all such reports be passed on promptly, which means, according to Mary T. Carden, one of the investigators responsible for the FDA's report, in "10-15 days". Carden noted one case where plasma with elevated levels of alanine aminotransferase, an indicator that the blood may harbour other viral infections, was erroneously shipped to the Swiss Red Cross and not reported to the FDA for two years. One Red Cross employee, when questioned about delays, had said "error reports were not a first priority".

Lewellys F. Barker, senior vice president of the American Red Cross, said that the 386 reports "are in the process of being reviewed", and that "when a region discovers an error, they correct it immediately". He said that the Red Cross will provide a written response to the FDA's allegations in 60 days. Diane Gershon

\section{Washington}

ize its major research projects by encouraging foreign companies and researchers to join them.

It is to be hoped that other ministries and government organizations will follow suit. Japanese scientists often complain that their research does not get the recognition it deserves in the West. But those scientists who are in universities and government research laboratories need only look as far as their kisha clubs to understand why they fail to get wider coverage in the Western press.

David Swinbanks

\section{KANSAI SCIENCE CITY}

\section{High-energy ions for rent in Japan \\ Tokyo}

ONE of the first of several new research institutes planned for the new Kansai Science City being built not far from the cities of Osaka, Kyoto and Nara was opened on 5 July. The Ion Engineering Center is equipped with the world's most powerful ion implantation apparatus (8 $\mathrm{MeV}$ ), and will 'rent' its facilities to both private and public users. The centre provides one example of how organizers of the science city are attracting private investment.

The centre is managed by a semi-public corporation established in 1988 by the New Energy and Industrial Technology Development Organization (NEDO) with an initial investment of $¥ 7,800$ million (\$52 million) from NEDO, the Osaka, Kyoto and Nara prefectural governments, and several private companies, including Kansai Electric Power Company, Nippon Steel, Hitachi, and Matsushita Electric Industrial Company.

Private companies, universities and national research institutes and laboratories will be able to rent the centre's ion implanter and ion deposition apparatus for research on new devices and materials, including solar cells, fuel cells, highperformance sensors, superconductors and biomaterials. A separate company, the Ion Engineering Research Institute Corporation, will also conduct its own research at the centre.

The centre joins the Advanced Telecommunications Research Institute International (ATR), the first institute to open in the science city (see Nature 338, 285; 1989). ATR is backed by the Ministry of Post and Telecommunications and is financed with funds derived from the dividends of government-held shares of the semi-privatized domestic telecommunications company Nippon Telegraph and Telephone (NTT). When completed early next century, the science city is expected to attract a total investment of $\$ 25,000$ million dollars, much of it from the private sector.

David Swinbanks 